\title{
Blended learning in a first-year language class: Evaluating the acceptance of an interactive learning environment
}

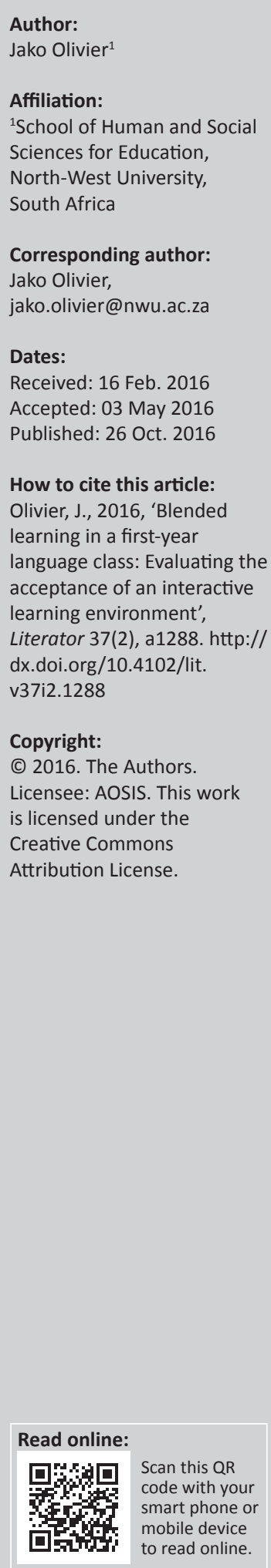

Increasingly blended learning, as a combination of face-to-face and online instruction is applied in university classrooms. In this study the use of an interactive learning environment (ILE), within a Sakai-based learning management system, as well as face-to-face teaching and learning in a first-year Afrikaans language class is explored. The Technology Acceptance Model (TAM) was employed by means of a survey and the Structure Equation Model was used to explore factors relevant to this first-year class. In addition, qualitative research was conducted through an open questionnaire in order to determine the perceptions regarding the blended learning context and the ILE. It was found that students are generally able to function within the ILE and they are quite positive towards the use of the learning environment for learning and teaching. However, it is clear that some students still prefer printed study material. Despite the fact that students indicated that they use the ILE daily, actual usage statistics did not always correspond. Finally, this paper makes suggestions with regard to adapting teaching in terms of students' behaviour based on their computer anxiety and Internet self-efficacy as well as the perceived usefulness and ease of use of the ILE.

Vervlegte leer in 'n taalklas op eerstejaarsvlak: Beoordeling van die aanvaarding van 'n interaktiewe leeromgewing. Vervlegte leer, as kombinasie van gesig-tot-gesig en aanlyn onderrig, word toenemend in universiteitsklaskamers toegepas. In hierdie studie is die gebruik van 'n interaktiewe leeromgewing (IL), binne 'n Sakai-gebaseerde leerbestuurstelsel, sowel as gesig-totgesig-onderrig en -leer in 'n Afrikaanse taalklas op eerstejaarsvlak ondersoek. Die tegnologieaanvaardingsmodel(TAM) is deur middel van'n vraelys gebruiken'nstruktuurvergelykingsmodel is ingespan om faktore wat relevant is tot hierdie eerstejaarsklas te ondersoek. Verder is kwalitatiewe navorsing gedoen deur middel van 'n oopvraelys ten einde die persepsies rondom die konteks waarin die vervlegte leer plaasgevind het asook die IL te bepaal. Daar is gevind dat die studente in die algemeen in staat is om binne die IL te funksioneer en dat hulle positief is teenoor die gebruik van die IL ten opsigte van onderrig en leer. Dit is egter ook duidelik dat studente eerder gedrukte studiemateriaal verkies. Ten spyte van die feit dat studente aandui dat hulle die IL daagliks gebruik, het werklike gebruikstatistiek nie hiermee ooreengestem nie. Ten slotte word daar in hierdie artikel voorstelle gemaak ten opsigte van die aanpassing van onderrig ten opsigte van studente se gedrag op grond van hul rekenaarangs, internetselfdoeltreffendheid asook die waargenome bruikbaarheid en gebruiksgemak van die IL.

\section{Introduction}

The increase in use of learning management systems (LMSs), the fact that the divide between open distance (cf. Esterhuizen 2012:1-2) and traditional face-to-face teaching and learning is fading as well as economic considerations has led to a move from a paper-based study guide to an electronic study guide or interactive learning environment (ILE) in teaching contexts (cf. Pool \& Du Toit 2014:90). In this instance a study guide is regarded as a document or online version thereof guiding learning and not a digitised coursebook or textbook. The ILE is therefore an online environment in which course information, assessment plans, lesson outlines, prescribed reading, electronic resources, online links and assessments are systematically organised in order to facilitate online learning by students.

This study relates to the conceptual framework associated with the Technology Acceptance Model (TAM) as devised by Davis (1986) as well as social cognitive theory relating to self-efficacy (Bandura 1986, 1995; Davis 1989:321; Venkatesh \& Davis 1996:453). The TAM was employed in 
this study in order to explore attitudes towards an ILE in a language class. The TAM describes the motivational processes that mediate between system characteristics and user behavior' (Davis 1986:10). The TAM has its theoretical foundations in the measurement of performance within system utilisation as well as use-performance expectancy (Davis 1989:320-321).

The focus of this article is to explore the TAM in terms of an implemented ILE in the Sakai-based LMS called eFundi. Hence, an ILE is a specific environment for a specific course or module placed on a platform called an LMS. Despite some studies done on the use of this particular LMS in general (Pool 2014; Pool \& Du Toit 2014; Tredoux 2012; Vermeulen 2011) this study was an attempt to assess acceptance of a specific ILE replacing a paper-based guide in an Afrikaans and Dutch language first-year module at higher education level.

The acceptance of the ILE in a language class and the context of blended learning is firstly explored in this article. This context implies a degree of computer literacy which can be interpreted in terms of Prensky's (2001) concepts of digital natives and digital immigrants. An integral part of this research is the study guide as an instrument guiding learning and teaching. Study guides or ILEs are explored in terms of existing literature on the topic as well as an overview of the process followed in this particular study. The empirical part of this article involves the TAM as it was employed by means of a survey which also included open-ended questions exploring attitudes towards the ILE even further.

The research problem approached in this study relates to the manner in which a blended learning approach with an ILE in an Afrikaans and Dutch language module is perceived and accepted in general and in terms of the TAM.

\section{The interactive learning environment and blended learning Blended learning}

The use of an ILE together with face-to-face classroom interaction implies a blended learning approach. In this regard, Marsh (2012:3) defines blended learning as 'any combination of different methods of learning, different learning environments, different learning styles'. Blended learning can also be described as an integrated approach to learning with traditional face-to-face and computer supported, web-based or online approaches (cf. Hew \& Cheung 2014:2-3; Holmes \& Gardner 2006:10; Littlejohn \& Pegler 2007:1, 26; Pool 2014:21-23; Pool \& Du Toit 2014:91-92).

An ILE can act as a way to structure and guide learning in a blended manner across different mediums (online and faceto-face). In this regard, Pool and Du Toit (2014:106-107) found that such an environment 'supported blended learning through creating an online platform, which supported connectivity and interaction'. The Sakai-based LMS called eFundi (cf. Pool 2014:55; Tredoux 2012:78-83; Vermeulen
2011:2-3) is explored in this article in terms of a specific ILE for a specific language module. The use of this platform entails students and lecturers to be computer literate, however, these literacy levels vary between individuals and designations of digital natives and immigrants are appropriate in this instance.

\section{Digital migration status and immigrant anxiety}

Often the distinction is made between digital natives and digital immigrants. Marc Prensky describes learners who are more computer literate than their teachers as digital natives. On the other hand, the teachers are then considered to be digital immigrants (Prensky 2001:1-6). Shelly et al. (2006:7) observe that due to exposure to computers the learners in schools can be described as 'digital students' or 'digital kids' who are 'hypercommunicators who use multiple tools to communicate; multitaskers who do several things at once with ease; and goal oriented as they pursue multiple goals at the same time'. Often this stereotype is also applied to university students with similar concerns in terms of the apparent divide between technological skills between lecturers and students.

However, Bennett, Maton and Kervin (2008) question the 'moral panic' around digital natives. The relationship with technology is clearly more complex. In this regard, Bennett et al. (2008:783) assert: 'While technology is embedded in their lives, young people's use and skills are not uniform. There is no evidence of widespread and universal disaffection, or of a distinctly different learning style the like of which has never been seen before'. This view is also supported by other studies (Helsper \& Eynon 2010; Kennedy et al. 2008; Margaryan, Littlejohn \& Vojt 2011). Hence, a nuanced view of computer literacy should be considered even in higher education contexts.

Any blended learning context would expose the divide between so-called digital natives and immigrants. As such levels of computer literacy, and associated anxieties, are also therefore an aspect that needs to be explored in instances where technology is employed for teaching and learning. The influence of computer anxiety and computer self-efficacy on attitudes, use and ability to acquire new skills is evident in the literature (Khorrami-Arani 2001:18; Sam, Othman \& Nordin 2005:207; Simsek 2011:177-179). In this research, computer and specifically Internet self-efficacy is also an important aspect as users of an ILE must believe that they can function within such an environment and expand on their skills. Bandura (1986:391) defines self-efficacy as 'people's judgments of their capabilities to organise and execute courses of action required to attain designated types of performances' (cf. Bandura 1997:2). These judgements influence the way users act in terms of computer-based interfaces such as an ILE.

This study reports on how an ILE was implemented and perceived by users. In the next section the concept of a study guide and the process of developing an ILE are discussed. 


\section{From study guide to interactive learning environment}

As a matter of policy, study guides have been used to direct and manage learning at the institution, in which this study was conducted, for many years. The institution's Study Guide Policy describes a study guide as 'a document that aims to guide the education process of students to facilitate effective learning and the acquisition of the learning outcomes in all modules' (NWU 2007:1). In addition, importantly it is also noted that this document 'may be either paper-based and/or electronic; or fully online; or a blend of paper-based and online elements' (NWU 2007:2). In general, according to De Villiers (1995:12) study guides are supposed to orientate a student towards a course by correctly formulating learning aims in terms of teaching and learning events as well as being a management document through which a learning facilitator can plan the course of a particular module.

Study guides can be used effectively to direct learning. De Villiers (1995:2) notes that such a document can promote selfdirected learning (cf. Tredoux 2012:9-46) as well as problemsolving in adult learners. The purpose of a study guide, and within the context of this study electronic versions thereof, is to support self-directed learning. Self-directed learning can be described as 'a process in which individuals take the initiative, with or without the help of others, in diagnosing their learning needs, formulating learning goals, identifying human and material resources for learning, choosing and implementing appropriate learning strategies and evaluating learning outcomes' (Knowles 1975:18).

In a sense the LMS manages learning and tracks progress (Tredoux 2012:5); however, in each module the managing of learning realised by means of electronic study guides or ILEs. Pool (2014:55) describes the purpose of an electronic study guide as 'an interactive electronic support mechanism which will guide students in a structured way to achieve relevant outcomes'. Furthermore, Pool and Du Toit (2014:93) state that '[w]ith recent advances in technology, e-guides are becoming an excellent management, learning and assessment tool in the teaching learning process, replacing printed study guides'.

In a study investigating the use of an ILE in a blended Technology Education graduate course Pool (2014:187) determined that students found such an environment 'simple and easy to use' and that a combination of instruction provided online and during contact sessions contributed to the successful completion of online learning activities. Therefore, support for the implementation of an ILE in a blended learning approach is apparent.

Despite having interactive learning environments on the LMS it is clear from the literature that in the past eFundi has not been used interactively. In this regard, Vermeulen (2011:228) noted that 'the number of respondents who do not use eFundi interactively is an alarming $77.5 \%{ }^{\prime}$ as found in a study conducted with university lecturers. Furthermore, Vermeulen
(2011:228) adds that the 'e-learning platform is merely used as a distribution mechanism and not as a tool to enhance learning'. Only by guiding students through the content on eFundi (in this instance by means of the Lessons functionality) as well as by including tools accommodating interaction (such as the Comments and Wiki tools) could the concerns raised by the literature be addressed.

In this study it was important to determine how the ILE was perceived by the users. As such, the TAM - as discussed in the next section - was employed to investigate this matter.

\section{Technology Acceptance Model}

Despite the existence of other models, such as the Theory of Reasoned Action (TRA) and the Theory of Planned Behaviour (TPB) (cf. Venkatesh 1999:240), the Technology Acceptance Model (TAM) has been used and tested extensively internationally (Chen \& Tseng 2012; Davis 1989; Davis, Bagozzi \& Warshaw 1989; Venkatesh 1999; Venkatesh \& Davis $1996,2000)$ as well as in the context in which this research was conducted (Esterhuizen et al. 2012a). The TAM was proposed by Davis (1986:24) and can be used to explain and predict user acceptance of information technology (cf. Chen \& Tseng 2012; Davis 1989; Davis et al. 1989:985-989; Esterhuizen et al. 2012a:81; Venkatesh \& Davis 1996:452, 2000:186).

The TAM and the different factors mediating towards actual system use is represented by Venkatesh and Davis (1996:453) as shown in Figure 1 (cf. Davis et al. 1989:985).

According to Chen and Tseng (2012:399) the TAM was developed through the modification of the TRA which, in turn, was employed to 'explain and predict user acceptance of information systems'. This model also involved exploring the beliefs, attitudes and intentions that have an effect on the use of a specific technology. A number of studies have used this model, as well as adaptations thereof, in order to determine the nature of the acceptance or adoption of specific technologies (Chen \& Tseng 2012:399).

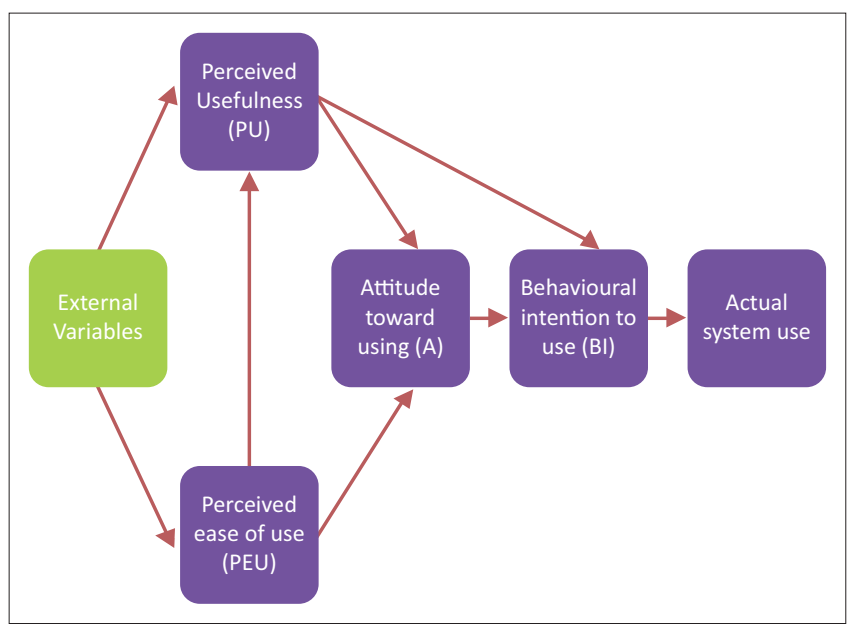

Source: Davis, F.D., Bagozzi, R.P. \& Warshaw, P.R., 1989, 'User acceptance of computer technology: A comparison of two theoretical models', Management Science 35(8), 982-1003. http://dx.doi.org/10.1287/mnsc.35.8.982

FIGURE 1: Technology Acceptance Model. 
Davis (1986:24) notes that behavioural intention 'reflects a decision that the person has made, and as such gets formed through a process of mental deliberation, conflict and commitment that may span a significant time period'. The process of behavioural intention was central in this study in order to determine acceptance of an ILE as it is also informed by the other variables noted in Figure 1. In the next section the implementation of the ILE, as context to this research, is discussed.

\section{Implementation}

This study involved the linguistics part of a first-year Afrikaans and Dutch language module. As stated before, this study relates to a move from a paper-based study guide to an online ILE. A simpler version of the ILE was trialled with another first-year group in 2014, this was followed by an enhanced ILE implemented in 2015 as well as subsequent research with this particular group.

For the purpose of the module an ILE was created on the Sakai-based LMS called eFundi (cf. Pool 2014:55; Tredoux 2012:78-83; Vermeulen 2011:2-3) following the guidelines for the instructional design of an e-guide, as proposed by Pool and Du Toit (2014:93-95; 105-106). In this module the supplemental model (Twigg 2003:30,32) of blended learning was employed. With the supplemental model the face-toface course is maintained, supplemented with 'technologybased, out-of-class activities to encourage greater student engagement with course content' (Twigg 2003:32). The contents of the employed ILE is summarised in Figure 2.

The empirical part of this article involves a mixed-method approach to research where both quantitative and qualitative research techniques and methods are combined (cf. Johnson \& Onwuegbuzie 2004:14). The methodology is described in terms of the research participants and the measurement model in the next section, followed by an overview of the data collection and data analysis.

\section{Methodology Research participants}

For this article first-year students in an Afrikaans linguistics module were used. Convenience sampling was employed in

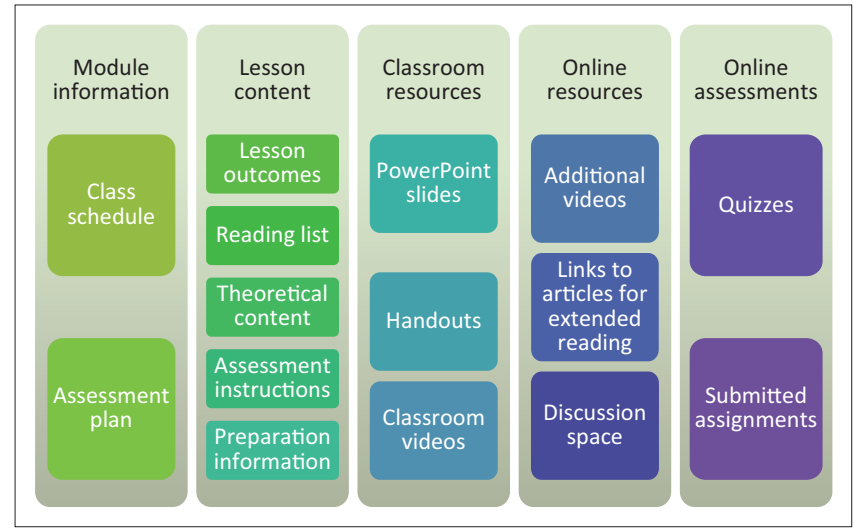

FIGURE 2: Contents of the interactive learning environment. this research as the researcher was constrained by the number of students in the specific class $(n=108)$. After eliminating absent students, students who opted not to take part in the research as well as incomplete questionnaires only 82 responses remained for analysis, resulting in a response rate of $75.9 \%$.

The group seemed to be diverse in terms of field of study. The profile of the participants is summarised in Table 1.

Most of the respondents were female and 19 and younger with regard to age. In terms of field of study most students were studying within the field of Communication Studies, followed by Psychology and Languages (i.e. Creative Writing, English, French, German, Setswana and/or Translation and Interpreting Studies).

\section{Measurement model}

The TAM was employed by means of a survey and analysed using a Structure Equation Model (SEM) (cf. Chen \& Tseng 2012). The survey involved 22 statements with a Likert scale from 1 (strongly disagree) to 7 (strongly agree). Refer to Addendum A for the details of the questionnaire - as based on the questionnaire for a survey conducted by Chen and Tseng (2012). For the purpose of this study the questionnaire was translated into Afrikaans (cf. Addendum B). A back translation was done of the questions in order to determine equivalence between the source text and translation.

\section{Data collection and analysis}

In addition to the TAM items, information on computer literacy, the means of access to the LMS and usage details were also gained by means of open questions in the questionnaire. This was done in order to determine the perceptions regarding the blended learning context and the ILE. In this regard, the following questions were posed to the respondents:

- Give an impression of your level and nature of your computer literacy.

TABLE 1: Profile of the research participants.

\begin{tabular}{lcc}
\hline Characteristic & Number & $\%$ \\
\hline Gender & 62 & 75.6 \\
Female & 20 & 24.4 \\
Male & & \\
Age & 66 & 80.5 \\
19 and younger & 15 & 18.3 \\
$20-24$ & 1 & 1.2 \\
$25-29$ & 0 & 0.0 \\
$30-34$ & 0 & 0.0 \\
35 and older & & \\
Field of study & 14 & 17.1 \\
Languages & 19 & 23.2 \\
Psychology & 24 & 29.3 \\
Communication studies & 13 & 15.9 \\
Theology & 9 & 11.0 \\
Law & 3 & 3.7 \\
Other & & \\
\hline
\end{tabular}


- Give an impression of your level and nature of your Internet literacy.

- How did you experience eFundi?

- How did you experience the electronic study guide?

- How could the electronic study guide be improved?

As stated before the analysis involved a SEM, which is described by Chen and Tseng (2012:400) as a 'regressionbased multivariable technique combined with path analysis'. Prior to the discussion of the statistical analysis more information is provided in terms of ethical issues.

\section{Ethical considerations}

Participation in this study was totally voluntary and informed consent was obtained from the participants. These individuals were allowed to withdraw from the study at any point. As the author of this article is a lecturer to the selected participants a student assistant conducted the data collection outside of official class times. Ethical clearance for this research was granted by the North-West University Research Ethics Regulatory Committee (NWU-RERC) as part of a wider project on blended learning in language classrooms. The following ethics number was awarded for this research: NWU-00331-14-A7.

\section{Discussion}

Apart from the survey items related to the TAM and the biographical information, mentioned earlier, the respondents were also asked to indicate the nature of their computer literacy, how they access the ILE and how often they access the ILE (actual usage statistics of the ILE was also gained).

The respondents were required to indicate which level of computer literacy they have in terms of formal instruction or not. For the sake of comparison, the respondents could choose between having completed Information Technology (IT) or Computer Applications Technology (CAT) as school subjects; having other computer training; being self-taught or having no computer training at all. The results of this question are summarised in Figure 3.

The majority (54\%) of respondents indicated that they were self-taught; this leaves $42 \%$ of the respondents having had some training while $4 \%$ indicated that they had

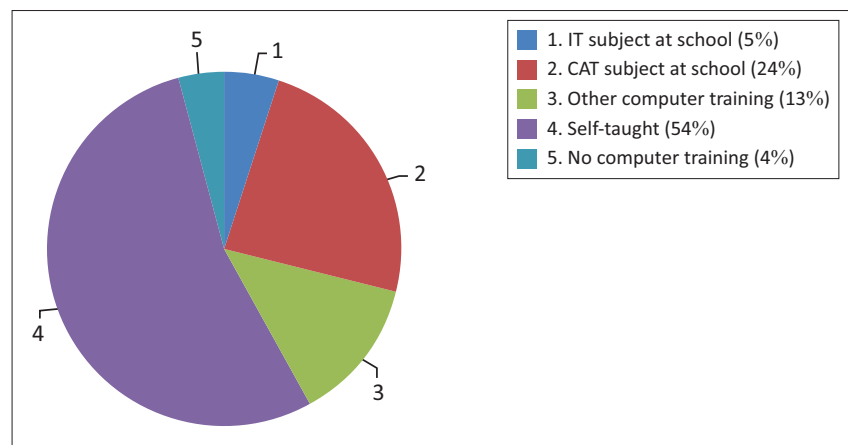

FIGURE 3: Devices used to access the interactive learning environment. no training at all. The group with no training is of concern because they are expected to be able to function within the ILE without the necessary computer literacy support.

A number of devices can be used to access the ILE. According to the participants in this study, the following devices were most used when accessing the ILE (Figure 4):

The preference of using cell phones to access the ILE on the LMS supports the findings by Olivier (2011:64). In her study $63.8 \%$ of a selection of students (of the same institution as reported on in this study) indicated that they strongly agreed or agreed that the ILE is accessed by means of mobile devices. However, most respondents in this study preferred using their own laptops to access the ILE.

When the participants were asked how often the ILE was accessed the majority of them indicated that they access it at least once a day (Figure 5).

Despite the high reported frequency of access to the ILE the actual statistics derived from the LMS showed an average of 43.8 visits for the semester. A difference between perceived use and actual use in general was also noted by Davis (1989:335) in his study. Figure 6 provides an overview of all the individual participants' actual visits to the ILE.

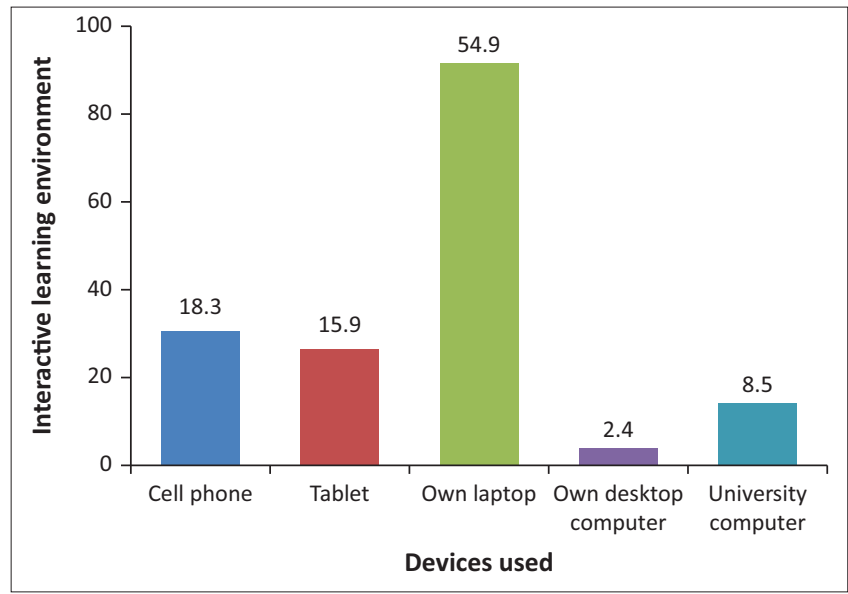

FIGURE 4: Devices used to access the interactive learning environment.

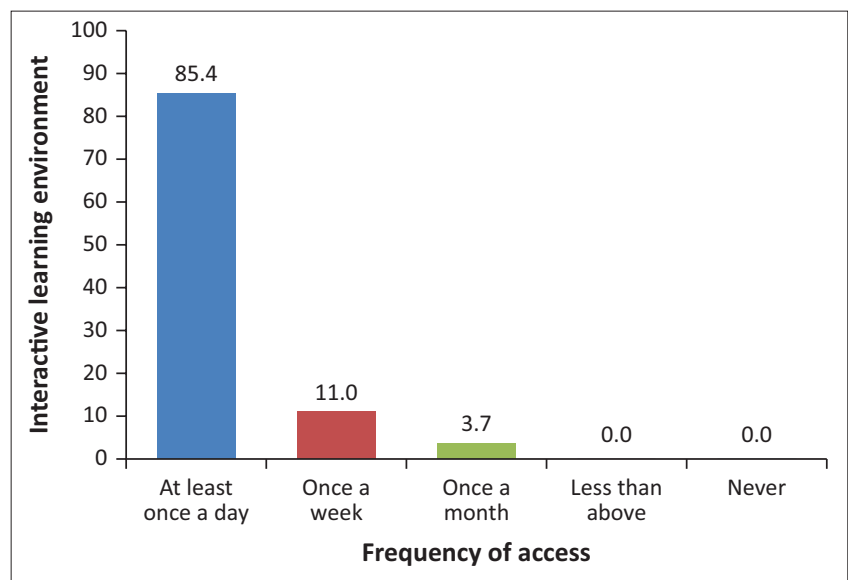

FIGURE 5: Reported frequency of access to interactive learning environment. 


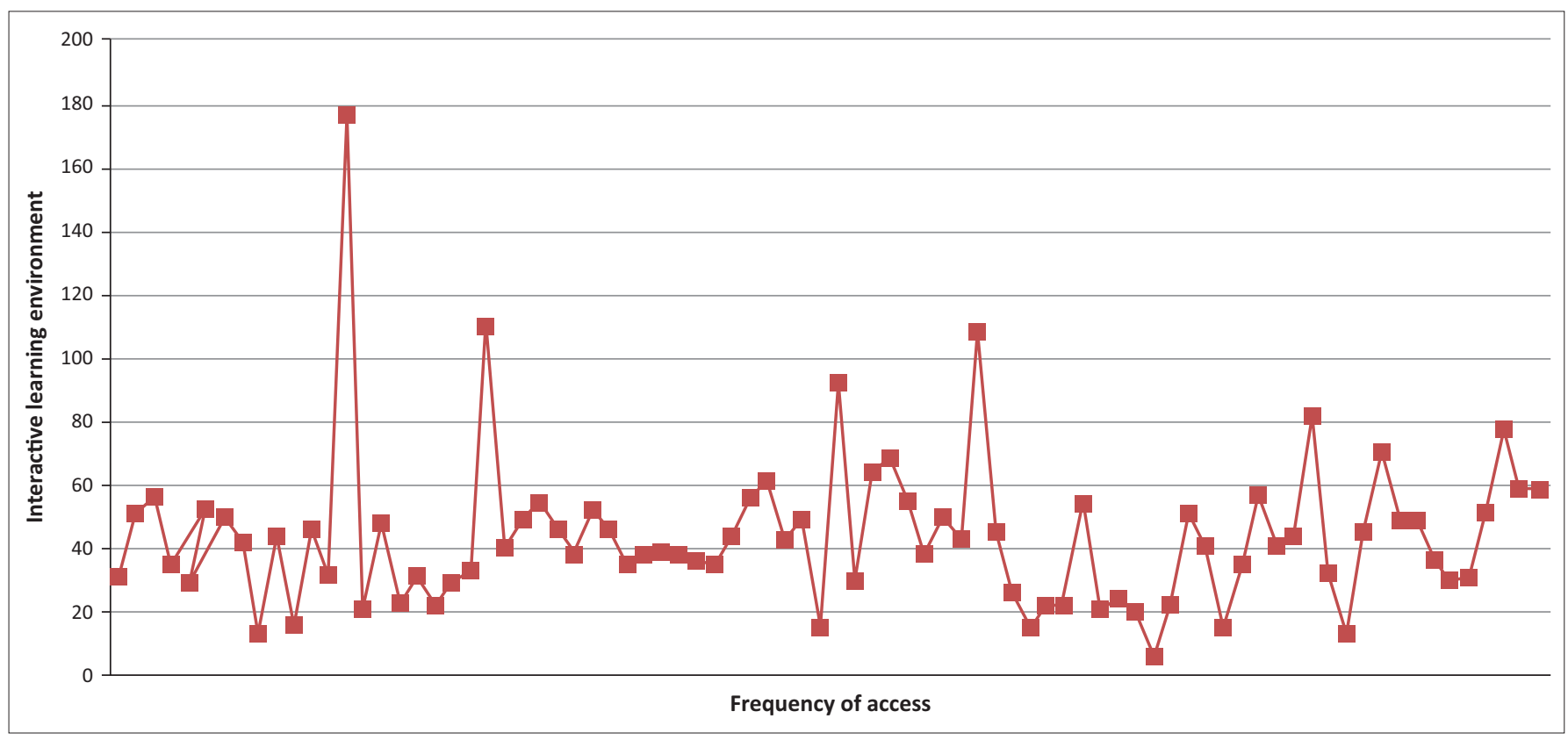

FIGURE 6: Actual frequency of access to interactive learning environment.

The participant with the highest number of visits to the ILE accessed it 176 times. In contrast, another participant only accessed the ILE five times throughout the whole semester. With most respondents visiting between 20 and 60 times within the 12 weeks of classroom contact time, an average of between one and five visits per week seems to be the pattern

\section{Quantitative analysis}

The quantitative analysis included testing the instrument's reliability, comparison of variables, investigating correlations as well as exploring cause relationships. The first statistical analysis involved reliability analysis of the TAM's factors. The results of this step are reported in Table 2.

Apart from Motivation to use the values of the other five factors were satisfactory with Cronbach's alpha higher than 0.6 which is acceptable for exploratory research (cf. Hair et al. 2014:123)

All the additional variables in terms of computer literacy, device and frequency of access were compared in terms of the TAM factors. Only instances with statistical or practical significance are reported in this article. Firstly, it is evident that self-taught users of computers are statistically significant more prone to Computer anxiety in comparison with respondents who had CAT as a school subject as is clear in Table 3.

Some statistically significant results were also found in terms of the type of device used (cf. Table 4).

In addition, in terms of the use of the cell phones and tablets as devices, as combined for the purposes of this analysis, statistical significant differences were apparent in terms of laptops and Computer anxiety as well as Perceived usefulness

\begin{tabular}{lc} 
TABLE 2: Cronbach's alpha for the identified factors. \\
\hline Factor & Cronbach's $\alpha$ \\
\hline Motivation to use & 0.496 \\
Computer anxiety & 0.789 \\
Internet self-efficacy & 0.782 \\
Perceived usefulness & 0.874 \\
Perceived ease of use & 0.837 \\
Behavioural intention & 0.883
\end{tabular}

with small effect in practice while Perceived ease of use displayed medium effect in practice. In this regard, respondents who used cell phones and tablets to access the ILE were more prone to Computer anxiety than those who used laptops. However, in terms of Perceived usefulness and Perceived ease of use respondents accessing the ILE with laptops achieved higher scores than those who prefer cell phones and tablets.

Apart from the comparisons noted above, correlations between the different variables were also explored as summarised in Table 5 .

Large, practical significant relationships are evident in terms of Computer anxiety together with Internet self-efficacy and Perceived ease of use; Perceived ease of use with Internet selfefficacy and Behavioural intention. No correlation was found between actual usage of the ILE and any of the factors. The correlation between Computer anxiety and Internet self-efficacy is significant, as some degree of self-efficacy is necessary in order to counter any anxieties when using online technologies and as such contribute to the ability of being able to develop skills in using resources such as ILE.

It was also important to explore the cause relationship of the TAM in this specific context. In this study a $100 \%$ mediation from the revised structure model was achieved. This is illustrated in Table 6. 
TABLE 3: Comparison in terms of computer literacy.

\begin{tabular}{|c|c|c|c|c|c|c|}
\hline \multirow[t]{2}{*}{ Factor } & \multicolumn{2}{|c|}{ Means } & \multirow[t]{2}{*}{$t$} & \multirow[t]{2}{*}{ Degrees of freedom } & \multirow[t]{2}{*}{$p$} & \multirow[t]{2}{*}{$d$} \\
\hline & CAT subject in school + & Self-taught & & & & \\
\hline Computer anxiety & 2.04 & 3.30 & -3.796 & 41.788 & $<0.001^{\mathrm{a}}$ & $0.94^{b}$ \\
\hline Internet self-efficacy & 6.41 & 6.31 & 0.36 & 25.706 & 0.722 & 0.09 \\
\hline Perceived usefulness & 5.11 & 5.65 & -1.524 & 62.000 & 0.133 & 0.31 \\
\hline Perceived ease of use & 5.43 & 5.68 & -0.773 & 62.000 & 0.442 & 0.16 \\
\hline Behavioural intention & 4.78 & 4.82 & -0.123 & 36.138 & 0.903 & 0.03 \\
\hline
\end{tabular}

CAT, computer applications technology.

$p$-values are reported, but not interpreted, since a convenience sample instead of a random sample was used.

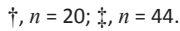

a, Statistically significant at 0.05 level according to t-test results for independent groups.

b, Practically significant according to Cohen.

TABLE 4: Comparison in terms of device.

\begin{tabular}{|c|c|c|c|c|c|c|}
\hline \multirow[t]{2}{*}{ Factor } & \multicolumn{2}{|c|}{ Means } & \multirow[t]{2}{*}{$t$} & \multirow[t]{2}{*}{ Degrees of freedom } & \multirow[t]{2}{*}{$p$} & \multirow[t]{2}{*}{$d$} \\
\hline & Cell phone or tablet $\uparrow$ & Laptop: & & & & \\
\hline Computer anxiety & 3.29 & 2.56 & 2.318 & 71.000 & $0.023^{a}$ & $0.48^{b}$ \\
\hline Internet self-efficacy & 6.26 & 6.41 & -0.724 & 61.873 & 0.472 & 0.16 \\
\hline Perceived usefulness & 5.21 & 5.79 & -2.022 & 51.462 & $0.048^{a}$ & $0.46^{b}$ \\
\hline Perceived ease of use & 5.13 & 5.97 & -3.267 & 71.000 & $0.002^{\mathrm{a}}$ & $0.63^{c}$ \\
\hline Behavioural intention & 4.37 & 5.06 & -1.956 & 44.837 & 0.057 & 0.43 \\
\hline
\end{tabular}

$\dagger, n=28 ; \uparrow, n=45$.

a, Statistically significant at 0.05 level according to t-test results for independent groups.

b, Small effect in practice according to Cohen.

c. Medium effect in practice according to Cohen.

TABLE 5: Correlations between the different variables.

\begin{tabular}{|c|c|c|c|c|c|c|}
\hline Variable & Correlation & Computer anxiety & Internet self-efficacy & Perceived usefulness & Perceived ease of use & Behavioural intention \\
\hline \multirow[t]{2}{*}{ Computer anxiety } & Correlation coefficient & - & $-0.549^{* * *}$ & $-0.235^{*}$ & $-0.522^{* *}$ & $-0.291^{* *}$ \\
\hline & Sig. (2-tailed) & - & 0.000 & 0.033 & 0.000 & 0.008 \\
\hline \multirow[t]{2}{*}{ Internet self-efficacy } & Correlation coefficient & $-0.549^{* *}$ & - & 0.143 & $0.514^{* * *}$ & $0.354^{* * *}$ \\
\hline & Sig. (2-tailed) & 0.000 & - & 0.201 & 0.000 & 0.001 \\
\hline \multirow[t]{2}{*}{ Perceived usefulness } & Correlation coefficient & $-0.235^{*}$ & 0.143 & - & $0.460^{* *}$ & $0.456^{* *}$ \\
\hline & Sig. (2-tailed) & 0.033 & 0.201 & - & 0.000 & 0.000 \\
\hline Perceived ease of use & Correlation coefficient & $-0.522^{* *}$ & $0.514^{* *}$ & $0.460^{* *}$ & - & $0.573^{* * *}$ \\
\hline & Sig. (2-tailed) & 0.000 & 0.000 & 0.000 & - & 0.000 \\
\hline \multirow[t]{2}{*}{ Behavioural intention } & Correlation coefficient & $-0.291^{* *}$ & $0.354^{* *}$ & $0.456^{* *}$ & $0.573^{* *}$ & - \\
\hline & Sig. (2-tailed) & 0.008 & 0.001 & 0.000 & 0.000 & - \\
\hline
\end{tabular}

*, Correlation is significant at the 0.05 level (2-tailed); **, Correlation is significant at the 0.01 level (2-tailed).

$\sim 0.3$ medium, practical visible relationship.

$\sim 0.5$ large, practical significant relationship.

TABLE 6: Cause relationship in terms of $100 \%$ mediation.

\begin{tabular}{lcc}
\hline Cause relationship & Direct effect & $p$ \\
\hline $\begin{array}{l}\text { Computer anxiety > } \\
\text { perceived ease of use }\end{array}$ & -0.458 & 0.002 \\
$\begin{array}{l}\text { Internet self-efficacy }> \\
\text { perceived ease of use }\end{array}$ & 0.340 & 0.008 \\
$\begin{array}{l}\text { Perceived ease of use }> \\
\text { behavioural intent }\end{array}$ & 0.694 & $<0.001$ \\
\hline
\end{tabular}

Cheng and Tsen (2012:404) found that '[p]erceived usefulness and perceived ease of use emerged as intervening variables that mediated the impact of external variables (motivation to use, computer anxiety, and Internet self-efficacy) on intentions to use web-based e-learning system for in-service education'. Venkatesh and Davis (1996:472) also found that computer self-efficacy (just another name for the category and equivalent to Internet self-efficacy in this study) can act as a determinant of the perceived ease of use. However, in this study only Perceived ease of use acts as mediator towards Behavioural intent. With the revised model this study obtained satisfactory goodness of fit statistics with the following values: $\chi 2 / \mathrm{df}=1.68, \mathrm{CFI}=0.884$ and $\mathrm{RMSEA}=-0.092$. This

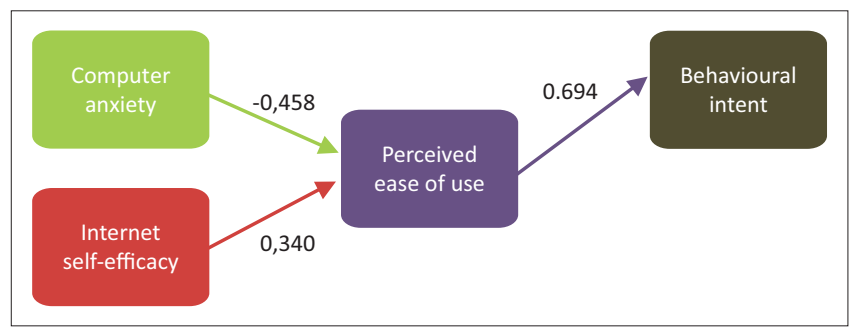

FIGURE 7: Revised Structure Model.

revision does not imply that this model could not work in other instances, for this specific population and in this instance, however, the mediation appears to be dissimilar as indicated above. The revised structure model is represented visually in Figure 7.

It is evident that the students in this study are generally computer literate. However, for some students this is still a problem. Most of the students access the ILE on their own laptops and most of them access the ILE at least once a 
day (although specific actual usage statistics do not agree as this data were retrieved from the ILE's statistics on the LMS). In the Revised TAM, in this research context, Motivation to use and Perceived usefulness do not act as mediators. However, the prominence of Computer anxiety and Internet self-efficacy in terms of Perceived ease of use is evident.

In instances such as the one researched in this study, the importance of countering computer anxiety and building on Internet self-efficacy is therefore very clear. Only through research focus on these areas can perceptions around the acceptance of an ILE be advanced in order to change students' behaviour towards ILEs.

To supplement the results of the TAM, open-ended questions were also employed in order to qualitatively explore the respondents' attitudes towards the ILE.

\section{Qualitative analysis}

In terms of the qualitative data in this study, a series of openended questions were included in the questionnaire. In this regard, inductive coding was done in order to determine themes from the data, as opposed to testing any specific existing theoretical issues. Comments were recorded in Afrikaans and are presented here translated into English. At the end of each response the respondent number and line of the comment is provided in square brackets.

Four clear themes and a number of suggestions towards the improvement of the ILE were identified from the data.

\section{Theme 1: Computer anxiety}

Simsek (2011:178) describes computer anxiety as a multidimensional construct 'characterised as an affective (to some extent emotional) response' where an individual experiences fear and apprehension in using computer technology. Some degree of computer anxiety (cf. Sam et al. 2005; Simsek 2011) was evident from the responses from the students:

I sometimes find technology hard to use, but luckily there are many people around me that can help. [73:1]

My computer literacy is surely not the best and I would benefit from some training. [61:1]

My Internet skills are average and I do sometimes struggle finding things I am looking for. [43:2]

I don't use the Internet. I find using the Internet very difficult. [73:2]

Esterhuizen (2012:146) notes technophobia among open distance learning students from the same institution as is reported on in this article. Interestingly, in that study the open-ended questions rather than Likert scale responses showed latent technophobia among the particular group of respondents. In this study a similar trend was confirmed among a selection of the respondents.

\section{Theme 2: Internet and computer self-efficacy}

Chen and Tseng (2012:401) describe Internet self-efficacy as the extent to which students use the Internet to engage in relevant learning activities. Among the respondents Internet and computer literacy varies:

I had a distinction in IT in matric. I've been working with computers since I was very young. [71:1]

Despite the fact that I have never had any training I have quite good computer skills with most programs. [11:1]

It is enough to allow me to pass. [16:1]

I am not computer literate and do not like working on a computer, but I can do some basic things. [88:1]

The various levels of computer literacy is evident from these responses as the respondents fall on a continuum between just about having basic knowledge to almost expert usage of computers. Venkatesh and Davis (1996:473) note the importance of computer self-efficacy in the acceptance of any computer-based system.

Problems regarding computer literacy among students were also reported by Pool (2014:200) and Esterhuizen et al. (2012a:87) with students at the same institution as reported on in this article. Unlike, as stated by Vermeulen (2011:172), the research population used in this study was not introduced to the university's LMS prior to the commencement of classes and the researcher scheduled a lesson in a computer laboratory to introduce the students to the LMS. This was a compulsory session conducted in the third week of semester. Anecdotal evidence suggests that students had a positive experience of this intervention. It is therefore important for students to be supported in terms of acquiring sufficient computer literacy levels. This type of development implies some sort of self-efficacy in terms of computers and in particular, use of the Internet.

Pool and Du Toit (2014:107) state that 'Students will have to be prepared to use e-guides efficiently in order to reap the full learning benefits the blended mode offers them'. This process starts with computer literacy and the ability to develop in using particular computer environments or applications and ultimately some perceived ease of use.

\section{Theme 3: Perceived ease of use}

The construct Perceived ease of use relates to the extent to which the ILE was easy to use by the respondents. The following responses were recorded in this regard:

It is a very helpful and user-friendly source with condensed information for all my subjects.

It is definitely the first place I go for help or when I have questions. [29:2]

It is a wonderful pest. It is comfortable to get the information from eFundi, but less so when you don't have access to a computer. [38:1]

I hated it at the beginning, but I realised that it really helps me to keep my homework and summaries up to date. [16:2]

I don't really like eFundi because it is very busy and it confuses a person sometimes. Not all the classes have information on eFundi and so it is difficult to know what homework should be done. [9:1] 
I would have preferred the study guide in paper format. I like to make notes on my papers and books. I prefer to study in this way. [4:2]

It is not as convenient as a normal (printed) study guide. [6:1]

It is useful as it contains previous lessons. It is more eco-friendly. [14:1]

I print out parts of the study guide before each class and work through it. I use it to study. [38:2]

Some students indicated that they found the ILE very easy to use and were quite positive towards the environment. However, a number of negative responses are reported under this theme. In this regard, the concerns regarding the ILE were focussed on the structure of eFundi, the fact that not all modules use eFundi or use it consistently and especially the fact that respondents still also prefer some printed material.

\section{Theme 4: Behavioural intent}

Behavioural intent relates to specific actions or behaviours in terms of the ILE. Some statements were identified to be relevant in terms of behavioural intent:

I go on eFundi every day in order to go through the day's work and to make written notes for tests. [2:2]

If something is not clear, then I consult the guide. [14:2]

I save the study guide on my computer and study from it there. [21:2]

I did not use the study guide. [22:3]

I use the study guide on my tablet and laptop and it is therefore nice to access it in class. [48:1]

Clearly behaviour, which could relate to some apprehensiveness towards the use of the ILE at the beginning of a course, could change due to enactive mastery experiences (Bandura 1997:3) where self-efficacy increased after continued use of the ILE. As stated under Theme 1, a class meeting was scheduled in a computer laboratory in order to ensure that all the students were able to access the ILE. Apart from this initial use of the environment in the classroom further use was encouraged by means of content, quizzes, assignments and interactions on the ILE. In this way opportunities were created for enactive mastery experiences by increasing the use of the ILE. The initial classroom use of the ILE also facilitated vicarious experiences (Bandura 1997:3) in that students could experience the successes of fellow students. Hence, students could experience the successes of others and improve themselves.

In addition to the afore-mentioned themes the respondents also made suggestions for improvement of the ILE:

- More clear facts must be included so that my learning takes less time. [1:2]

- More links can be added with additional information on certain topics. [12:6]

- Less information. Unnecessary information should be removed. [16:5]
- It would be nice if parts of the study guide could be highlighted. [52:1]

- The whole study guide must be provided so that we can work ahead. [57:3]

- The study guide should be used more often in class. [77:2]

- Everything can be more complete. [82:1]

- More examples can be provided and the content could be simpler. [88:4]

- A printed study guide is required. [4:5, 6:1, 9:2, 12:4, 19:2, 21:1, 22:2, 27:3, 31:1; 32:2, 34:1, 38:2, 39:5, 45:1, 49:2, 55:3, $58: 1,61: 2,63: 2,72: 1,75: 3,80: 1,85: 1,86: 2,87: 1$ and 88:2]

The above-mentioned statements provide some practical suggestions towards the improvement and effective creation of ILEs in higher education contexts.

\section{Conclusion}

This study explored acceptance as well as user perceptions regarding the implementation of an ILE in the linguistics part of an Afrikaans and Dutch first-year module. The use of an online-based ILE together with face-to-face class meetings in this module implies a blended learning approach. Important to this approach is computer and more specifically the Internet literacy levels of the individuals involved. In this regard, it is important to note that despite perceptions of students being digital natives, quite often they (together with lecturers) are in fact digital immigrants with varying degrees of computer literacy.

In order to facilitate the use of ILEs, content was adapted from a print-based study guide. Such guides are meant to guide learning and facilitate self-directed learning among students. It is important to note LMSs such as eFundi are not always used as interactively as they could be and it was important in the implementation of the ILE in this study to use the available tools effectively.

In order to explain and predict user acceptance of the ILE the TAM was used. The empirical part of this article involved a mixed-method approach to research where results from the TAM were combined with additional closed and open-ended questions. Clearly the majority of the respondents were fairly computer literate; however, most of them were self-taught. The presence of some students who are not computer literate is a concern. Most respondents accessed the ILE by means of their own laptops, followed by the use of their own cell phones and tablets (as opposed to university devices). Despite the fact that respondents indicated that they access the ILE at least once a day, actual usage statistics proved a lower frequency of access. With the implementation of the TAM, unlike with the original model, Motivation to use and Perceived usefulness did not act as mediators. The revised model, constructed for this study based on the statistical analysis, in this study obtained satisfactory goodness of fit statistics. Furthermore, large, practical significant relationships are evident in terms of Computer anxiety together with Internet self-efficacy and Perceived ease of use as well as 
Perceived ease of use with Internet self-efficacy and Behavioural intention.

From the qualitative data some degree of computer anxiety was clear. This aspect also related to computer literacy issues as well as varying degrees of Internet self-efficacy. Furthermore, the way students viewed the LMS and ILE could also potentially influence their actual behaviour in terms of the ILE. Apart from some positive attitudes towards the ILE, some respondents did question the structure and general implementation of the LMS. A very important requirement among respondents was the need for printed material instead or in addition to the ILE. The behavioural intent in terms of the ILE also showed differences, but the need for mastery experiences is clear. The respondents also provided suggestions towards the improvements of the ILE in terms of content and structure.

Significant contributions of this study include the Afrikaans version of the TAM (Addendum B), adding to the body of research on the use of ILEs in the context of South Africa and specifically the North-West University as well as questioning the use of the TAM with the original factors in all contexts.

In terms of future research it is evident that the TAM is a useful tool to gauge perceptions and acceptance of ILEs. However, additional qualitative data can complement the results from the TAM as was done in this study. In addition, due to the feedback received, future ILEs and the use thereof can be adapted to meet the needs of students. It is also therefore advised that lecturers in similar situations conduct action research in terms of the implementation of ILEs in order to improve acceptance of the environments.

\section{Acknowledgements Competing interests}

The author declares that he has no financial or personal relationships which may have inappropriately influenced him in writing this article.

\section{References}

Bandura, A., 1997, Self-efficacy: The exercise of control, W.H. Freeman, New York.

Bandura, A., 1986, Social foundations of thought and action: A social cognitive theory, Prentice Hall, Englewood Cliffs.

Bandura, A., 1995, 'Exercise of personal and collective efficacy in changing societies', in A. Bandura (ed.), Self-efficacy in changing societies, pp. 1-45, Cambridge University Press, New York.

Bennett, S., Maton, K. \& Kervin, L., 2008, 'The "digital natives" debate: A critical review of the evidence', British Journal of Educational Technology 39(5), 775-786. $\mathrm{http}: / / \mathrm{dx}$.doi.org/10.1111/j.1467-8535.2007.00793.x

Chen, H. \& Tseng, H., 2012, 'Factors that influence acceptance of web-based e-learning systems for the in-service education of junior high school teachers in Taiwan' Evaluation and Program Planning 35(3), 398-406. http://dx.doi.org/10.1016/j. evalprogplan.2011.11.007

Davis, F.D., 1986, 'A technology acceptance model of empirically testing new end-user information systems: Theory and results', PhD thesis, Massachusetts Institute of Technology.

Davis, F.D., 1989, 'Perceived usefulness, perceived ease of use, and user acceptance of information technology', MIS Quarterly 13(3), 319-340. http://dx.doi. org/10.2307/249008
Davis, F.D., Bagozzi, R.P. \& Warshaw, P.R., 1989, 'User acceptance of computer technology: A comparison of two theoretical models', Management Science 35(8), 982-1003. http://dx.doi.org/10.1287/mnsc.35.8.982

De Villiers, P.F., 1995, 'Die ontwerp van doelgerigte studiegidse vir volwasseneleerders: 'n selfdoenmodule vir leerbegeleiers', MEd-skripsie, RAU, Johannesburg.

Esterhuizen, H.D., 2012, 'The integration of learning technologies in open distance learning at the North-West University', PhD thesis, North-West University, Potchefstroom.

Esterhuizen, H.D., Blignaut, S., Ellis, S.M. \& Els, C.J., 2012a, 'ODL students' perceived computer literacy competencies, expectations of support intention to use and perseverance', Turkish Online Journal of Distance Education 13(4), 76-94.

Esterhuizen, H.D., Blignaut, A.S., Els, C.J. \& Ellis, S.M., 2012b, 'Computer literacy learning emotions of ODL teacher-students, in T. Amiel \& B. Wilson (eds.), Proceedings of EdMedia: World Conference on Educational Media and Technology 2012. Association for the Advancement of Computing in Education (AACE) Denver, CO, pp. 586-595.

Hair, J.F., Black, W.C., Babin, B.J. \& Anderson, R.E., 2014, Multivariate data analysis, Pearson, Harlow.

Helsper, E.J. \& Eynon, R., 2010, 'Digital natives: Where is the evidence?', British educational research journal 36(3), 503-520. http://dx.doi.org/10.1080/ 01411920902989227

Hew, K.F. \& Cheung, W.S., 2014, Using blended learning: Evidence-based practices, Springer, Singapore.

Holmes, B. \& Gardner, J., 2006, E-learning: Concepts and practice, SAGE, London.

Johnson, R.B., \& Onwuegbuzie, A.J., 2004, 'Mixed methods research: a research paradigm whose time has come', Educational researcher, 33(7):14-26, Oct. http://dx.doi.org/10.3102/0013189x033007014

Kennedy, G.E., Judd, T.S., Churchward, A., Gray, K., \& Krause, K.L, 2008, 'First year students' experiences with technology: Are they really digital natives?', Australasian Journal of Educational Technology 24(1), 108-122. http://dx.doi. org/10.14742/ajet.1233

Khorrami-Arani, O., 2001, 'Researching computer self-efficacy', International Education Journal 2(4), 17-25.

Knowles, M.S., 1975, Self-directed learning: A guide for learners and teachers, Follett, Chicago, IL.

Littlejohn, A. \& Pegler, C., 2007, Preparing for blended e-learning, Routledge, London.

Margaryan, A., Littlejohn, A. \& Vojt, G., 2011. 'Are digital natives a myth or reality? University students' use of digital technologies', Computers \& Education 56(2), 429-440. http://dx.doi.org/10.1016/j.compedu.2010.09.004

Marsh, D., 2012, Blended learning creating learning opportunities for language learners, Cambridge University Press, Cambridge.

NWU, 2007, Study guide policy, viewed 08 July 2015, from http://www.nwu.ac.za/ sites/www.nwu.ac.za/files/files/i-governance-management/policy/8P-8.1.6.1study_guides_e.pdf

Olivier, V., 2011, 'Managing mobile learning in a higher education environment', MBA Mini-dissertation, North-West University, Potchefstroom.

Pool, J., 2014, 'An investigation of communities of inquiry within a blended mode of delivery for technology education', PhD thesis, North-West University, Potchefstroom.

Pool, J. \& Du Toit, A., 2014, 'The design and development of an e-guide for a blended mode of delivery in a teacher preparation module', Progressio 36(2), 90-109.

Prensky, M., 2001, 'Digital natives, digital immigrants', On the Horizon 9(5), 1-6. http://dx.doi.org/10.1108/10748120110424816

Sam, H.K., Othman, A.E.A. \& Nordin, Z.S., 2005, 'Computer self-efficacy, computer anxiety, and attitudes toward the internet: A study among undergraduates in Unimas', Educational Technology \& Society 8(4), 205-219.

Shelly, G.B., Cashman, T.J., Gunter, G.A. \& Gunter, R.E., 2006, 'Teachers discovering computers: Integrating technology and digital media in the classroom', 4th edn., Thomson Course Technology, Boston, MA.

Simsek, A., 2011, 'The relationship between computer anxiety and computer selfefficacy', Contemporary Educational Technology 2(3), 177-187.

Tredoux, C., 2012, 'The potential of a learning management system to enhance selfdirected learning', MEd dissertation, North-West University, Potchefstroom.

Twigg, C.A., 2003, 'Improving learning and reducing costs: New models for online learning', Educause Review 38(5), 28, 30, 32-36, 38

Venkatesh, V., 1999, 'Creation of favorable user perceptions: Exploring the role of intrinsic motivation', MIS Quarterly, 23(20), 239-260. http://dx.doi. org $/ 10.2307 / 249753$

Venkatesh, V. \& Davis, F.D., 1996, 'A model of the antecedents of perceived ease of use: Development and test', Decision Sciences, 27(3), 451-481. http://dx.doi. org/10.1111/j.1540-5915.1996.tb01822.x

Venkatesh, V., \& Davis, F.D., 2000, 'A theoretical extension of the technology acceptance model: Four longitudinal field studies', Management Science 46(2), 186-204. http://dx.doi.org/10.1287/mnsc.46.2.186.11926

Vermeulen, L., 2011, 'Key human factors in the e-readiness of academic employees at higher education institutions', DLitt et Phil thesis, University of South Africa, Pretoria.

Appendix starts on the next page $\rightarrow$ 


\section{Appendix 1}

\section{Survey items as adapted from Chen and Tseng (2012)}

\section{Motivation}

You use eFundi because:

1. MU1: Web-based e-learning is less constrained by spatial limitations.

2. MU2: Web-based e-learning is not constrained by time.

3. MU3: I can fully control web-based e-learning progress.

\section{Computer anxiety}

4. CA1: I am worried that I do not know how to make the computer finish the things I want to do.

5. CA2: I feel troubled regarding some work that can only be completed by using a computer.

6. CA3: When I face error messages on the computer, I do not know what to do.

7. CA4: I feel scared in terms of operating products related to computer and technology.

\section{Internet self-efficacy}

Your self-evaluation of your ability in using the Internet:

8. ISE1: I am confident that I can connect to the web pages I want to browse.

9. ISE2: I am confident that I can use the Internet to download the information I need.

10. ISE3: I am confident that I can use the mouse to click on the web pages I need.
11. ISE4: I am confident that I can use the search engine to search for information.

\section{Perceived usefulness}

Your views towards web-based e-learning systems:

12. PU1: Advancing studies through using eFundi can help my learning be more efficient.

13. PU2: Advancing studies through using eFundi can help me acquire the information I want to acquire.

14. PU3: Advancing studies through using eFundi can be helpful to my work or learning.

15. PU4: Advancing studies through using eFundi can improve my learning ability.

\section{Perceived ease of use}

16. PEU1: It is easy for me to learn how to engage in advancing studies through eFundi.

17. PEU2: It is easy for me to independently operate eFundi to advance.

18. PEU3: It is easy to acquire knowledge by using eFundi to advance studies.

\section{Behavioural intention}

19. BI1: In the future I would use eFundi (or similar systems) to engage in in-service education.

20. BI2: I am willing to use eFundi (or similar systems) to replace other methods of in-service education.

21. BI3: If there are learning needs, I would choose eFundi (or similar systems) to engage in in-service education.

22. BI4: On the whole, I would use the method of eFundi (or similar systems) for in-service education.

Appendix continued on the next page $\rightarrow$ 


\section{Appendix 2}

\section{Survey items in the translated Afrikaans version \\ Motivering}

U gebruik eFundi (as vorm van webgebaseerde e-leer) want:

1. MU1: Webgebaseerde e-leer word minder beïnvloed deur ruimtelike beperkings.

2. MU2: Webgebaseerde e-leer word nie deur tyd beperk nie.

3. MU3: Ek kan die proses van webgebaseerde e-leer ten volle beheer.

\section{Rekenaarangs}

4. CA1: Ek is bekommerd dat ek nie weet hoe om met die rekenaar te doen wat ek wil doen nie.

5. CA2: Ek voel bekommerd oor sommige werk wat net op die rekenaar gedoen kan word.

6. CA3: As ek ' $n$ foutboodskap op die rekenaar kry, weet ek nie wat om te doen nie.

7. CA4: Ek voel bang om goed te gebruik wat met rekenaars of tegnologie te doen het.

\section{Selfversekerdheid op die Internet}

Dui die versekerdheid van jou vaardighede op die Internet aan:

8. ISE1: Ek is seker ek kan webwerwe opspoor wat ek benodig.

9. ISE2: Ek is seker dat ek die Internet kan gebruik om inligting af te laai.

10. ISE3: Ek is seker dat ek die muis kan gebruik om na webwerwe te gaan wat ek benodig.
11. ISE4: Ek is seker dat ek soekenjins (soos Google) kan gebruik om inligting te soek.

\section{Bruikbaarheid}

Jou mening ten opsigte van webgebaseerde e-leerstelsels:

12. PU1: Die aanvul van my studies deur eFundi maak my leer meer effektief.

13. PU2: Die aanvul van my studies deur efundi help my om inligting makliker te vind.

14. PU3: Die aanvul van my studies deur eFundi is nuttig vir my toekomstige werk en as ek leer.

15. PU4: Die aanvul van my studies deur eFundi kan my leervermoë verbeter.

\section{Gebruiksgemak}

16. PEU1: Dit is vir my maklik om te leer hoe om my studies te verbeter met behulp van eFundi.

17. PEU2: Dit is vir my maklik om op my eie eFundi te gebruik om te vorder.

18. PEU3: Dit is maklik om kennis op te doen deur eFundi te gebruik.

\section{Gedragsintensie}

19. BI1: In die toekoms sal ek eFundi (of stelsels soos eFundi) wil gebruik vir opleiding.

20. BI2: Ek is bereid om eFundi (of stelsels soos eFundi) in die plek van ander onderrigmetodes te gebruik.

21. BI3: Indien ek ooit leerbehoeftes het, sal ek kies om eFundi (of stelsels soos eFundi) vir indiensopleiding te gebruik.

22. BI4: In die algemeen sal ek eFundi (of stelsels soos eFundi) vir indiensopleiding gebruik. 